\title{
DAMPAK PANDEMI COVID-19 TERHADAP KINER- JA PELAKSANAAN ANGGARAN SATUAN KERJA DI PROVINSI KALIMANTAN BARAT
}

\author{
Egi Dwi Purnomo'
}

\begin{abstract}
${ }^{1}$ Kantor Pelayanan Perbendaharaan Negara Sintang, Indonesia egidpr@gmail.com

Submitted: 11 Juli 2021 Revised: 1 December 2021 Accepted: 5 December 2021

To realize good governance, the government implements Bureaucratic Reform. One of the areas of change that become the goal of bureaucratic reformation is Strengthening Performance Accountability. As a form of performance accountability, the Ministry of Finance establishes Budget Execution Performance Indicators (IKPA). The implementation of IKPA has experienced developments as well as challenges. In 2020, IKPA was challenged by the COVID-19 pandemic in Indonesia. With the COVID-19 Pandemic and budget refocusing, financial managers face formidable challenges. For that, the authors wanted to determine how the effect of the Pandemic of COVID-19 on the Budget Execution Performance at the Work Unit level in West Kalimantan Province. This research is a quantitative research using secondary data. The secondary data used is the Budget Execution Performance of the work unit in West Kalimantan Province for two years (2019 and 2020) which consists of 10 indicators. The testing technique of this study uses a paired sample t-test to determine the difference in the state of variables before the COVID-19 pandemic occurs with the time the COVID-19 pandemic occurs. The sample of this research is 499 work units in West Kalimantan Province. Among the ten indicators tested, only two indicators showed a significant decline, namely Management of Money Inventory and Budget Absorption. This shows that the Work Unit Budget Execution Performance in West Kalimantan Province is generally not affected by the COVID-19 pandemic and can even increase significantly on some performance indicators.
\end{abstract}

Keywords: IKPA; COVID-19; budget execution; performance; West Kalimantan

\section{ABSTRAK}

Dalam rangka mewujudkan good governance, pemerintah menerapkan Reformasi birokrasi. Salah satu area perubahan yang menjadi tujuan Reformasi birokrasi adalah Penguatan Akuntabilitas Kinerja. Sebagai bentuk akuntabilitas kinerja dalam pelaksanaan anggaran, Kementerian Keuangan menetapkan Indikator Kinerja Pelaksanaan Anggaran (IKPA). Penerapan IKPA terus mengalami perkembangan sekaligus tantangan. Tahun 2020, IKPA diuji oleh mulai masuknya pandemi COVID-19 di Indonesia. Dengan adanya Pandemi COVID-19 dan refocusing anggaran, pengelola keuangan pada satuan kerja sebagai ujung tombak dalam peningkatan kinerja pelaksanaan anggaran menghadapi tantangan yang sangat berat. Untuk itu, penulis ingin mengetahui bagaimana pengaruh Pandemi COVID-19 terhadap Kinerja Pelaksanaan Anggaran pada tingkat Satuan Kerja di Provinsi Kalimantan Barat. Penelitian ini adalah penelitian kuantitatif dengan mengunakan data sekunder. Data sekunder yang digunakan adalah Kinerja Pelaksanaan Anggaran Satuan kerja pada Provinsi Kalimantan Barat selama dua tahun (2019 dan 2020) yang terdiri atas 10 indikator. Teknik pengujian penelitian ini menggunakan uji beda paired sample t-test untuk mengetahui apakah ada perbedaan keadaan variabel sebelum terjadi pandemi COVID-19 dengan kelompok data saat terjadinya pandemi COVID-19. Sampel penelitian ini sebanyak 499 satuan kerja yang diperoleh dari Aplikasi OMSPAN (Online Monitoring Sistem Perbendaharaan dan Anggaran Negara). Dari sepuluh indikator yang diuji, hanya dua indikator yang menunjukan penurunan secara signifikan yaitu Pengelolaan Uang Persediaan, dan Penyerapan Anggaran. Hal ini menunjukan bahwa Kinerja Pelaksanaan Anggaran Satuan Kerja di Provinsi Kalimantan Barat secara umum tidak terpengaruh oleh Pandemi COVID-19 bahkan tetap dapat meningkat secara signifikan pada beberapa indikator kinerja.

Kata Kunci: IKPA; COVID-19; Kinerja; pelaksanaan anggaran; Kalimantan Barat 


\section{PENDAHULUAN}

Good Governance adalah suatu konsep pendekatan yang berorientasi kepada pembangunan sektor publik kepada pemerintahan yang baik (Mardiasmo: 2009). Menurut Mardiasmo, terdapat sembilan karakteristik pelaksanaan good governance yaitu partisipasi, kerangka hukum, transparansi, daya tanggap, berorientasi pada kepentingan masyarakat luas, keadilan, efisiensi dan efektivitas, akuntabilitas, dan visi strategik. Dari sembilan karakteristik tersebut, terdapat tiga pilar yang saling berkaitan untuk mewujudkan good governance yaitu transparansi, partisipasi, dan akuntabilitas, serta value for money (ekonomi, efisiensi, dan efektivitas).

Dalam rangka mewujudkan good governance, pemerintah menerapkan reformasi birokrasi. Menurut MenpanRB, reformasi birokrasi adalah upaya untuk melakukan pembaharuan dan perubahan mendasar terhadap sistem penyelenggaraan pemerintah dalam rangka mewujudkan tata kelola pemerintah yang baik (good governance). Salah satu area perubahan yang menjadi tujuan reformasi birokrasi dan sesuai dengan karakteristik good governance adalah Penguatan Akuntabilitas Kinerja.

Sebagai bentuk akuntabilitas kinerja birokrasi dalam pelaksanaan anggaran, Kementerian Keuangan melalui Peraturan Menteri Keuangan nomor 195/PMK.05/2018 tentang Monitoring dan Evaluasi Pelaksanaan Anggaran Belanja Kementerian Negara/Lembaga menetapkan Indikator Kinerja Pelaksanaan Anggaran (IKPA). IKPA adalah indikator yang ditetapkan Kementerian Keuangan selaku BUN untuk mengukur kualitas kinerja pelaksanaan anggaran belanja Kementerian Negara/Lembaga dari sisi kesesuaian terhadap perencanaan, efektivitas pelaksanaan anggaran, efisiensi pelaksanaan anggaran, dan kepatuhan terhadap regulasi. Kesesuaian terhadap perencanaan terdiri atas tiga indikator yaitu Revisi DIPA, Deviasi Halaman III DIPA, dan Pagu Minus. Efektivitas Pelaksanaan anggaran terdiri atas empat indikator yaitu Penyerapan Anggaran, Penyelesaian tagihan, konfirmasi capaian output, dan retur SP2D. Efisiensi pelaksanaan anggaran terdiri atas dua indikator yaitu Renkas dan kesalahan SPM. Sedangkan kepatuhan terhadap regulasi terdiri atas empat indikator yaitu Data Kontrak, Pengelolaan UP dan TUP, LPJ Bendahara, dan Dispensasi SPM.
Penerapan IKPA terus mengalami perkembangan sekaligus tantangan. Pada tahun 2020, IKPA mulai menerapkan indikator baru yaitu Konfirmasi Data Capaian Output. Menurut Peraturan Menteri Keuangan Nomor PER04/PB/2020 tentang Petunjuk Teknis Penilaian Indikator Kinerja Pelaksnaan Anggaran Belanja $\mathrm{K} / \mathrm{L}$, Konfirmasi data capaian output menunjukan rasio jumlah output yang terkonfirmasi terhadap total output yang dikelola oleh Satker atau K/L. Konfirmasi data capaian output bertujuan untuk mewujudkan belanja berkualitas sesuai dengan prinsip penganggaran berbasis kinerja. Namun pada tahun yang sama, IKPA juga diuji oleh mulai masuknya pandemi Coronavirus disease 2019 (COVID-19) di Indonesia.

Menurut World Health Organization (WHO), COVID-19 adalah penyakit menular yang disebabkan oleh jenis coronavirus yang baru ditemukan di Wuhan, Tiongkok, bulan Desember 2019. COVID-19 ini sekarang menjadi sebuah pandemi yang terjadi di banyak negara di seluruh dunia termasuk Indonesia. Manusia dapat tertular COVID-19 dari orang lain yang terinfeksi virus ini. COVID-19 mampu menyebar terutama dari orang ke orang melalui percikanpercikan dari hidung atau mulut yang keluar saat orang yang terinfeksi COVID-19 berbicara, batuk, dan bersin. Percikan-percikan ini relatif berat, sehingga perjalanannya tidak jauh dan mudah jatuh ke tanah dengan cepat. Oleh karena itu, penting bagi kita untuk menjaga jarak minimal satu meter dari orang lain. Percikan-percikan ini dapat menempel di benda dan permukaan lainnya di sekitar orang seperti meja, gagang pintu, dan pegangan tangan. Manusia dapat terinfeksi dengan menyentuh benda atau permukaan tersebut, kemudian menyentuh mata, hidung, atau mulut mereka.

Kalimantan Barat menjadi provinsi pertama di Kalimantan yang terdampak pandemi COVID-19 pada 12 Maret 2020, tetapi juga menjadi provinsi dengan jumlah kasus positif terendah berdasarkan jumlah keseluruhan maupun jumlah per kapita di Kalimantan. Hingga 31 Desember 2020, terdapat 3.118 kasus positif yang terdiri dari 349 kasus yang masih dirawat, sementara 2.742 kasus dinyatakan sembuh dan 27 kasus dinyatakan meninggal (tingkat kematian 0.8\%). Rincian kasus COVID-19 pada provinsi Kalimantan Barat dapat dilihat pada Tabel 1. 
JIADI: Jurnal Ilmu Administrasi dan Pemerintahan Indonesia Volume 02 No 02 December 2021 Pages 12O-128

Tabel 1. Rincian Kasus COVID-19 Pada Tahun 2020 di Provinsi Kalimantan Barat

\begin{tabular}{lcccc}
\hline Kab. / Kota & Kasus & Sembuh & Meninggal & Isolasi \\
\hline Pontianak & 983 & 853 & 21 & 109 \\
Singkawang & 188 & 159 & o & 29 \\
Mempawah & 117 & 101 & 1 & 15 \\
Kubu Raya & 482 & 435 & 0 & 47 \\
Kayong Utara & 35 & 33 & 0 & 2 \\
Ketapang & 188 & 159 & 0 & 29 \\
Melawi & 86 & 84 & 0 & 2 \\
Sanggau & 76 & 70 & 1 & 5 \\
Sekadau & 29 & 26 & 0 & 3 \\
Bengkayang & 87 & 70 & 0 & 17 \\
Sambas & 121 & 87 & 0 & 34 \\
Kapuas Hulu & 123 & 111 & 1 & 11 \\
Sintang & 377 & 346 & 1 & 30 \\
Landak & 181 & 166 & 2 & 13 \\
Luar Kalbar & 45 & 42 & 0 & 3 \\
\hline Total & 3.118 & 2.742 & 27 & 349 \\
\hline Sumber: data.kalbarp
\end{tabular}

Sumber: data.kalbarprov.go.id, 2020.

Selama tahun 2020, pemerintah telah mengeluarkan sejumlah kebijakan sebagai upaya menekan laju penularan. Pada bulan Maret 2020, Presiden menerbitkan Peraturan Pemerintah (PP) nomor 21 Tahun 2020 tentang Pembatasan Sosial Berskala Besar (PSBB) dalam Rangka Percepatan Penanganan Corona Virus Disease 2019 (COVID-19). Tindakan PSBB ini meliputi peliburan sekolah dan tempat kerja, pembatasan kegiatan keagamaan, dan juga pembatasan kegiatan di tempat atau fasilitas umum. Presiden juga mengeluarkan Peraturan Pemerintah Pengganti Undang-Undang (Perpu) Nomor 1 Tahun 2020 tentang Kebijakan Keuangan Negara dan Stabilitas Sistem Keuangan untuk Penanganan Pandemi Corona Virus Disease 2019 (COVID-19) dan/atau dalam rangka menghadapi ancaman yang membahayakan perekonomian nasional dan/atau stabilitas sistem keuangan serta Peraturan Presiden (PERPRES) Nomor 54 Tahun 2020 tentang Perubahan Postur dan Rincian Anggaran Pendapatan dan Belanja Negara Tahun Anggaran 2020. Efek dari adanya Perpu dan PERPRES tersebut adalah adanya refocusing anggaran terhadap seluruh Kementerian/Lembaga (K/L) dan daerah untuk dialokasikan ke dana kesehatan, bantuan sosial (bansos) dan mendukung dunia usaha khususnya Usaha Mikro Kecil dan Menengah (UMKM). Kegiatan yang direfokuskan antara lain seperti perjalanan dinas, rapat, kegiatan/proyek yang terhambat akibat adanya pandemik COVID-19 atau kegiatan yang dapat ditunda ke tahun berikutnya, dan kegiatan lainnya yang tidak dapat dilakukan pada masa Pandemi COVID-19.

Dengan adanya Pandemi COVID-19 dan refocusing anggaran, pengelola keuangan pada satuan kerja (satker) sebagai ujung tombak dalam peningkatan kinerja pelaksanaan anggaran pada K/L menghadapi tantangan yang sangat berat. Satker dituntut tetap bekerja untuk mewujudkan Good Governance dengan pagu anggaran yang terbatas akibat refocusing sembari menghindari penularan COVID-19 di lingkungan kerja. Provinsi Kalimantan Barat juga termasuk provinsi yang terdampak COVID-19. Untuk itu, penulis ingin mengetahui bagaimana pengaruh Pandemi COVID-19 terhadap Kinerja Pelaksanaan Anggaran pada tingkat Satuan Kerja pada salah satu provinsi di Indonesia yaitu Provinsi Kalimantan Barat. Judul yang akan diangkat oleh penulis adalah "Dampak Pandemi terhadap Kinerja Pelaksanaan Anggaran pada Satuan Kerja di Provinsi Kalimantan Barat”.

Berdasarkan uraian diatas, maka permasalahan yang akan diteliti dirumuskan sebagai berikut:

1. Bagaimana pengaruh pandemi COVID-19 terhadap Kinerja Pelaksanaan Anggaran Satker di Provinsi Kalimantan Barat?

2. Apa indikator kinerja yang paling terpengaruh terhadap Pandemi COVID-19?

Berdasarkan identifikasi diatas, maka tujuan penelitian ini dapat dirumuskan sebagai berikut:

1. Untuk menjelaskan secara empiris mengenai pengaruh pandemi COVID-19 terhadap Kinerja Pelaksanaan Anggaran Satker di Provinsi Kalimantan Barat;

2. Untuk mengetahui Indikator Kinerja Anggaran yang paling terpengaruh terhadap Pandemi COVID-19.

\section{Tinjauan Pustaka}

\section{Satuan Kerja}

Berdasarkan Peraturan Menteri Keuangan Nomor 190/PMK.05/2012 tentang Tata Cara Pembayaran Dalam Rangka Pelaksanaan Anggaran Pendapatan Dan Belanja Negara, Satuan Kerja yang selanjutnya disebut Satker adalah unit organisasi lini Kementerian Negara/Lemba- 
ga atau unit organisasi Pemerintah Daerah yang melaksanakan kegiatan Kementerian Negara/ Lembaga dan memiliki kewenangan dan tanggung jawab penggunaan anggaran. Pada tahun 2019, pada Provinsi Kalimantan Barat terdapat 550 satuan kerja yang memperoleh dana Anggaran Pendapatan dan Belanja Negara (APBN). Sedangkan tahun 2020, Satuan kerja yang memperoleh dana APBN menjadi 519 Satuan kerja.

Tabel 2. Rincian Satker per KPPN di Provinsi Kalimantan Barat

\begin{tabular}{lcc}
\hline \multicolumn{1}{c}{ KPPN Mitra } & 2019 & 2020 \\
\hline KPPN Pontianak & 267 & 253 \\
KPPN Singkawang & 85 & 82 \\
KPPN Ketapang & 51 & 47 \\
KPPN Sanggau & 69 & 64 \\
KPPN Sintang & 49 & 47 \\
KPPN Putussibau & 29 & 28 \\
\hline \multicolumn{1}{c}{ Total } & 550 & 519 \\
\hline
\end{tabular}

\section{Indikator Kinerja Pelaksanaan Anggaran}

Menurut Peraturan Menteri Keuangan Nomor 195/PMK.05/2018 tentang Monitoring dan Evaluasi Pelaksanaan Anggaran Belanja $\mathrm{K} / \mathrm{L}$, Indikator Kinerja Pelaksanaan Anggaran atau IKPA adalah indikator yang ditetapkan oleh Kementerian Keuangan selaku BUN untuk mengukur kualitas kinerja pelaksanaan anggaran belanja Kementerian Negara/Lembaga dari sisi kesesuaian terhadap perencanaan, efektivitas pelaksanaan anggaran, efisiensi pelaksanaan anggaran, dan kepatuhan terhadap regulasi. IKPA pertama kali digunakan untuk pengukuran dan apresiasi kinerja Pelaksanaan Anggaran K/L pada tahun 2014. Pada saat itu, pengolahan data IKPA dilakukan secara manual melalui proses cleansing sehingga masih terdapat risiko kehilangan data. Awareness mengenai IKPA juga masih rendah dan belum menjadi perhatian utama Kementerian Negara/Lembaga. Mulai tahun 2018, data IKPA diolah dan ditampilkan secara otomatis pada Aplikasi Online Monitoring SPAN (OMSPAN). IKPA menjadi salah satu Indikator Kinerja Utama (IKU) pengelolaan keuangan yang baik pada Kementerian Negara/Lembaga maupun Kementerian Keuangan sehingga awareness pada IKPA menjadi tinggi dan menjadi perhatian utama K/L sampai saat ini. Penilai- an IKPA juga digunakan sebagai dasar insentif anggaran sebagaimana diatur dalam Peraturan Menteri Keuangan Republik Indonesia Nomor 14/PMK.02/2020 tentang Tata Cara Pemberian Insentif Tahun Anggaran 2020 atas Kinerja Anggaran Kementerian Negara/Lembaga Tahun Anggaran 2019.

Dalam konteks monitoring dan evaluasi pelaksanaan anggaran sesuai dengan PMK Nomor 195/ PMK.05/ 2018 tentang Monitoring dan Evaluasi Pelaksanaan Anggaran Belanja Kementerian Negara/ Lembaga, IKPA digunakan sebagai alat untuk mengukur kualitas kinerja pelaksanaan anggaran belanja K/ L dari empat aspek, yaitu: kesesuaian dengan perencanaan, kepatuhan terhadap regulasi, efektivitas, dan efisiensi pelaksanaan kegiatan, dan terbagi ke dalam 13 indikator yang memanfaatkan data transaksi pengelolaan keuangan yang dilakukan oleh Satker.

Aspek Kesesuaian antara Perencanaan dan Pelaksanaan, pada prinsipnya menekankan bahwa DIPA merupakan dokumen pelaksanaan anggaran sebagai suatu hasil akhir perencanaan yang telah ditetapkan oleh $\mathrm{K} / \mathrm{L}$ sesuai rumusan RKA K/ L pada tahun pengusulannya, sehingga pada tahun berjalan, kegiatan pada DIPA seharusnya telah siap untuk dilaksanakan dan dilakukan pencairan anggaran sesuai rencana tersebut. Oleh karena itu, terhadap substansi program, kegiatan, dan output pada DIPA hendaknya tidak ada perubahan maupun pergeseran dan dapat dilaksanakan secara konsisten. Untuk mengukur kinerja perencanaan yang baik maka dapat dilihat dari tiga indikator berikut:

1. Indikator kinerja Revisi DIPA menunjukkan rasio antara jumlah revisi DIPA dalam kewenangan pagu tetap terhadap target revisi DIPA secara triwulanan.

2. Indikator kinerja Deviasi Halaman III DIPA menunjukkan tingkat kesesuaian realisasi anggaran bulanan terhadap perencanaan penarikan dana.

3. Indikator kinerja Pagu Minus menunjukkan rasio pagu minus (realisasi yang melebihi pagunya) terhadap pagu anggaran.

Aspek Kepatuhan Terhadap Regulasi, pada prinsipnya menekankan bahwa dalam melaksanakan anggarannya, Satker harus memenuhi norma-norma pengaturan batas waktu dalam memproses transaksi keuangan berdasarkan ketentuan yang berlaku di bidang pelaksanaan 
J1AD: Jurnal Ilmu Administrasi dan Pemerintahan Indonesia Volume 02 No 02 December 2021 Pages 120-128

anggaran. Hal ini dapat tercermin pada indikator berikut:

1. Indikator kinerja Penyampaian Data Kontrak menunjukkan rasio ketepatan waktu penyampaian dokumen ringkasan kontrak terhadap seluruh data kontrak yang didaftarkan ke KPPN.

2. Indikator kinerja Pengelolaan UP dan TUP menunjukkan rasio ketepatan waktu pertanggungjawaban UP dan TUP terhadap seluruh pertanggungjawaban UP dan TUP.

3. Indikator kinerja Penyampaian LPJ Bendahara menunjukkan rasio ketepatan waktu penyampaian LPJ oleh Bendahara Pengeluaraan terhadap seluruh kewajiban penyampaian LPJ.

4. Indikator kinerja Dispensasi Penyampaian SPM menunjukkan tingkatan dispensasi SPM yang melebihi batas waktu penyampaian pada akhir tahun anggaran.

Aspek efektivitas pelaksanaan kegiatan, pada prinsipnya menekankan bahwa alokasi anggaran yang tercantum pada DIPA dapat dieksekusi dengan baik, tepat, dan proporsional untuk mewujudkan output yang telah ditentukan. Efektivitas dalam melaksanakan suatu kegiatan pada DIPA dapat dilihat dari indikator berikut:

1. Indikator kinerja Penyerapan Anggaran menunjukkan rasio antara tingkat penyerapan anggaran terhadap target penyerapan yang ditentukan setiap triwulan.

2. Indikator kinerja Penyelesaian Tagihan menunjukkan rasio ketepatan waktu penyelesaian tagihan yang bersifat kontraktual (SPM-LS Kontraktual) terhadap seluruh kewajiban penyelesaian tagihan kontraktual yang diajukan ke KPPN.

3. Indikator kinerja Konfirmasi Capaian Output menunjukkan rasio antara jumlah output yang terkonfirmasi terhadap total output yang dikelola oleh Satker atau K/ L.

4. Indikator kinerja Retur SP2D menunjukkan rasio antara jumlah SP2D yang mengalami retur terhadap jumlah SP2D yang telah diterbitkan.

Aspek Efisiensi Pelaksanaan Kegiatan, pada prinsipnya menekankan bahwa dalam pelaksanaan kegiatan dan pembayaran tagihan atas penyelesaian pekerjaan dapat diselesaikan dengan tepat waktu, tepat sasaran, dan tepat jumlah sesuai dengan ketentuan yang berlaku, termasuk adanya jaminan ketersediaan dana pada saat tagihan disampaikan kepada KPPN. Untuk mengukur Efisiensi Pelaksanaan Kegiatan dapat dilihat dari indikator berikut:

1. Indikator kinerja Pengembalian/Kesalahan SPM menunjukkan rasio pengembalian/ kesalahan SPM oleh KPPN terhadap seluruh SPM yang diajukan ke KPPN.

2. Indikator kinerja Renkas menunjukkan rasio ketepatan waktu antara penyampaian Renkas (RPD Harian) terhadap seluruh kewajiban Renkas yang diajukan ke KPPN.

\section{Kerangka Konseptual}

Penelitian ini disusun berdasarkan hipotesis bahwa, variabel bebas yaitu Pandemi COVID-19 diduga memiliki pengaruh negatif terhadap variabel terikat yaitu Kinerja Pelaksanaan Anggaran satuan kerja Kementerian Negara/ Lembaga yang terdiri dari Pagu Minus, Data Kontrak, Pengelolaan UP dan TUP, LPJ Bendahara, Dispensasi SPM, Penyerapan Anggaran, Penyelesaian Tagihan, Retur SP2D, Renkas, dan Kesalahan SPM.

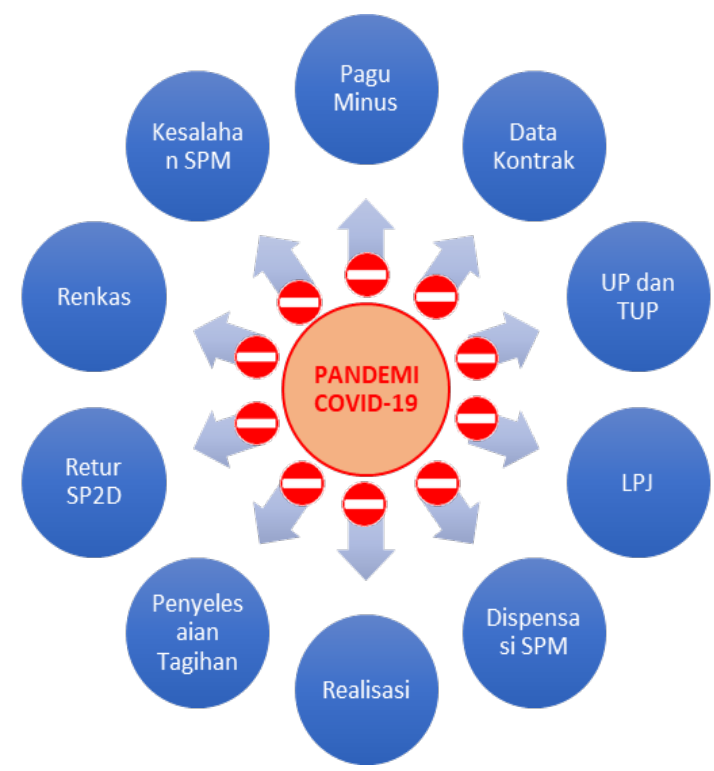

Gambar 1. Kerangka Konseptual

Penulisi menjabarkan kerangka konseptual diatas kedalam hipotesis berikut:

1. (H1) Pandemi COVID-19 menurunkan Nilai Kinerja Pagu Minus secara signifikan;

2. (H2) Pandemi COVID-19 menurunkan Nilai Kinerja Data Kontrak secara signifikan; 
3. (H3 - Pandemi COVID-19 menurunkan Nilai Kinerja Pengelolaan UP dan TUP secara signifikan;

4. (H4) Pandemi COVID-19 menurunkan Nilai Kinerja LPJ Bendahara secara signifikan;

5. (H5) Pandemi COVID-19 menurunkan Nilai Kinerja Dispensasi SPM secara signifikan;

6. (H6) Pandemi COVID-19 menurunkan Nilai Kinerja Penyerapan Anggaran secara signifikan;

7. (H7) Pandemi COVID-19 menurunkan Nilai Kinerja Penyerapan Anggaran secara signifikan;

8. (H8) Pandemi COVID-19 menurunkan Nilai Kinerja Retur SP2D secara signifikan;

9. (H9) Pandemi COVID-19 menurunkan Nilai Kinerja Renkas secara signifikan;

10. (H10) Pandemi COVID-19 menurunkan Nilai Kinerja Kesalahan SPM secara signifikan;

\section{METODE PENELITIAN}

Penelitian ini adalah penelitian kuantitatif dengan mengunakan data sekunder. Penelitian kuantitatif menurut Donmoyer dalam Given (2008) menggunakan pendekatan terhadap kajian empiris dengan melakukan pengumpulan data, menganalisisnya dan kemudian ditampilkan dalam bentuk numerik. Tujuan dari penelitian kuantitatif menurut Cooper dan Schindler (2006) adalah untuk melakukan pengukuran secara akurat terhadap obyek penelitian.

Peneliti akan melakukan analisis dengan menggunakan analisis deskriptif untuk mengetahui gambaran umum data sebelum dan sesudah pandemi. Data penelitian ini akan dibandingkan antara sebelum pandemi COVID-19 dengan setelah pandemic COVID-19. Oleh sebab itu, selanjutnya akan dilakukan pengujian dengan metode uji beda rata-rata untuk dua sampel berpasangan (paired sample t-test). Menurut Widiyanto (2013), paired sample t-test merupakan salah satu metode pengujian yang digunakan untuk mengkaji keefektifan perlakuan, ditandai adanya perbedaan rata-rata sebelum dan rata-rata sesudah diberikan perlakuan. Uji beda digunakan untuk mengevaluasi perlakuan (treatment) tertentu pada satu sampel yang sama pada dua periode pengamatan yang berbeda (Pramana, 2012).
Pada penelitian ini, 499 satker yang sama pada dua periode pengamatan yang berbeda yaitu periode sebelum terjadi pandemi COVID-19 (2019) dan periode saat terjadinya pandemi COVID-19 (2020). Salah satu syarat Paired sample t-test digunakan adalah data harus berdistribusi normal. Oleh karena itu, akan dilakukan uji normalitas sebelum uji beda Paired sample t-test. Pengolahan data dilakukan dengan menggunakan Aplikasi SPSS versi 25 dan Microsoft Excel 365.

Data sekunder adalah sumber data penelitian yang diperoleh peneliti secara tidak langsung melalui media perantara (diperoleh dan dicatat oleh pihak lain) yang umumnya berupa bukti, catatan atau laporan historis yang telah tersusun dalam arsip (data dokumenter) yang dipublikasikan dan tidak dipublikasikan (Indriantoro \& Supomo, 2002: 147). Sumber data sekunder dalam penelitian ini diperoleh dari basis data Direktorat Jenderal Perbendaharaan pada Aplikasi OMSPAN (Online Monitoring Sistem Perbendaharaan dan Anggaran Negara) pada Kantor Wilayah Direktorat Jenderal Perbendaharaan Provinsi Kalimantan Barat berupa Kinerja Pelaksanaan Anggaran Satker Kementerian/Lembaga pada Provinsi Kalimantan Barat selama tahun 2019 dan 2020 yang terdiri atas 13 indikator kinerja. Namun dalam penelitian ini hanya menggunakan 10 indikator yaitu Pagu Minus, Data Kontrak, Pengelolaan UP dan TUP, LPJ Bendahara, Dispensasi SPM, Penyerapan Anggaran, Penyelesaian Tagihan, Retur SP2D, Renkas, dan Kesalahan SPM dikarenakan terdapat dispensasi terkait dua indikator selama pandemi COVID-19 yaitu Revisi DIPA dan Deviasi Halaman III DIPA serta satu indikator yang baru diterapkan pada tahun 2020 yaitu Capaian Output.

Populasi pada penelitian ini adalah kinerja seluruh satker se-Kalimantan Barat yang menggunakan dana APBN selama dua tahun berturutturut (2019 dan 2020), dengan mengeliminasi satker yang tidak memperoleh Dana APBN pada tahun 2019 atau 2020. Eliminasi satker ini dikarenakan tidak adanya pembanding perubahan kinerja pelaksanaan anggaran satker tersebut antara sebelum Pandemi COVID-19 (2019) dengan setelah Pandemi COVID-19 (2020). Pengeliminasian ini diharapkan dapat membuat data yang akan diteliti berdistribusi normal. Dari hasil eliminasi, diperoleh 499 satuan kerja yang menjadi objek penelitian pada penelitian ini. 
J1AD: Jurnal Ilmu Administrasi dan Pemerintahan Indonesia Volume 02 No 02 December 2021 Pages 120-128

\section{HASIL DAN PEMbAhASAN}

\section{Uji Statistik Deskriptif}

Pengujian dalam penelitian ini dimulai dengan pengujian deksriptif yang memberikan gambaran atau deskripsi atau deskripsi atas data yang akan digunakan dalam penelitian ini, dengan hasil seperti pada Tabel 3 .

Berdasarkan Tabel 3, semua variabel yang diuji pada penelitian ini memiliki nilai rata-rata lebih besar dari nilai standar deviasi. Hal ini menunjukkan bahwa kualitas data dari variabel tersebut baik, karena nilai rata-rata yang lebih besar dari nilai standar deviasinya mengidentifikasikan bahwa standar eror dari variabel tersebut kecil dan pergerakannya tidak fluktuaktif (Ghozali, 2006).

\section{Uji Normalitas}

Uji normalitas digunakan untuk menentukan apakah data terdistribusi normal atau tidak. Dalam penelitian ini, uji normalitas menggunakan uji CLT (Central Limit Theorem) yaitu jika jumlah observasi cukup besar $(n>30)$, maka asumsi normalitas dapat diabaikan (Gujarati, 2003). Penelitian ini menggunakan jumlah $n$ sebesar $499>30$. Hal ini menunjukkan bahwa data dapat dikatakan berdistribusi normal dan dapat disebut sebagai sampel besar.

\section{Uji Paired Sample T-Test}

Pengujian paired sample T-Test dilakukan untuk melihat signifikansi perbedaan tiap pasangan variabel yang diuji. Pengujian sendiri dilakukan dengan melihat nilai $\Delta$ mean dan nilai signifikansi yang ada.

$\Delta$ Mean menunjukkan perubahan yang terjadi antara nilai rata-rata yang didapat sebelum terjadi pandemi dengan setelah terjadi pandemi.

$\Delta$ mean $=$ mean (2019) - mean (2020)

Sehingga apabila $\Delta$ mean bernilai negatif menunjukkan terjadi kenaikan dari tahun 2019 ke 2020, sedangkan $\Delta$ mean bernilai positif menunjukkan terjadi penurunan dari tahun $2019 \mathrm{ke}$ 2020.

Signifikansi (Sig.) atau probabilitas digunakan untuk menentukan apakah perbedaan variabel independen tersebut berpengaruh siginifikan terhadap variabel dependen yang ditimbulkan dengan melihat apabila nilai signifikansi di bawah 0,05 .

Table 3. Uji Statistik Deskriptif

\begin{tabular}{lrrrrr}
\hline & N & Min. & Max. & Mean & \multicolumn{1}{c}{ Std. } \\
Dev.
\end{tabular}


Dampak Pandemi Covid-19 terhadap Kinerja Pelaksanaan Anggaran Satuan Kerja di Provinsi Kalimantan Barat Egi Dwi Purnomo

Table 4. Uji Paired Sample T-Test

\begin{tabular}{|c|c|c|c|c|c|c|c|}
\hline & & $\begin{array}{c}\Delta \\
\text { Mean }\end{array}$ & Std. & $\begin{array}{l}\text { Std. } \\
\text { Error } \\
\text { Mean } \\
\end{array}$ & $\mathrm{t}$ & df & Sig. \\
\hline H1 & Pagu Minus (2019 - 2020) & & 5,47798 & 0,24523 & $-4,267$ & 498 & 0,000 \\
\hline $\mathrm{H} 2$ & Data Kontrak (2019 - 2020) & $-1,684$ & 16,697 & 1,139 & $-1,479$ & 214 & 0,141 \\
\hline $\mathrm{H}_{3}$ & $\begin{array}{l}\text { Pengelolaan UP dan TUP (2019 - } \\
\text { 2020) }\end{array}$ & 2,339 & 12,746 & 0,590 & 3,962 & 465 & 0,000 \\
\hline $\mathrm{H}_{4}$ & LPJ Bendahara (2019 - 2020) & $-2,323$ & 6,481 & 0,290 & $-8,005$ & 498 & 0,000 \\
\hline $\mathrm{H}_{5}$ & Dispensasi SPM (2019 - 2020) & $-0,050$ & 0,498 & 0,022 & $-2,245$ & 498 & 0,025 \\
\hline H6 & $\begin{array}{l}\text { Penyerapan Anggaran (2019 - } \\
\text { 2020) }\end{array}$ & & & 0,62376 & 11,935 & 498 & 0,000 \\
\hline $\mathrm{H}_{7}$ & $\begin{array}{l}\text { Penyelesaian Tagihan (2019 - } \\
\text { 2020) }\end{array}$ & & 9,05255 & 0,59305 & 0,905 & 232 & 0,366 \\
\hline H8 & Retur SP2D (2019 - 2020) & & 0,88485 & 0,03961 & $-1,770$ & 498 & 0,077 \\
\hline H9 & Renkas $(2019-2020)$ & & 4,01554 & 0,63491 &,- 458 & 39 & 0,650 \\
\hline & Kesalahan SPM $(2019-2020)$ & $-3,447$ & 8,528 & 0,382 & $-9,028$ & 498 & 0,000 \\
\hline
\end{tabular}

Sumber: Output SPSS 25.O for windows, 2021

Berdasarkan Tabel 4, dapat diketahui bahwa pada:

1. $\mathrm{H}_{1}, \mathrm{H}_{4}, \mathrm{H}_{5}$, dan $\mathrm{H}_{10}, \Delta$ mean bernilai negatif dan nilai signifikansi < 0,05. Negatif menunjukan terjadi kenaikan dan signifikansi < 0,05 menunjukan kenaikan terjadi secara signifikan sehingga dapat disimpulkan Hipotesis H1, H4, H5, dan H10 ditolak karena terjadi Peningkatan secara signifikan pada Indikator Pagu Minus, LPJ Bendahara, Dispensasi SPM, dan Kesalahan SPM.

2. $\mathrm{H} 2, \mathrm{H} 8$, dan $\mathrm{H} 9, \Delta$ mean bernilai negatif dan nilai signifikansi > 0,05 Negatif menunjukan terjadi kenaikan dan signifikansi $>$ 0,05 menunjukan kenaikan terjadi tidak secara signifikan sehingga dapat disimpulkan Hipotesis H2, H8, dan H9 ditolak karena terjadi Peningkatan namun tidak signifikan pada Indikator Data Kontrak, Retur SP2D, dan Renkas.

3. $\mathrm{H} 7, \Delta$ mean bernilai positif dan nilai signifikansi > 0,05. Positif menunjukan terjadi penurunan dan signifikansi > 0,05 menunjukan penurunan terjadi tidak secara signifikan sehingga dapat disimpulkan Hipotesis $\mathrm{H} 7$ ditolak karena terjadi Penurunan namun tidak signifikan pada Indikator Penyelesaian Tagihan.

4. $\mathrm{H}_{3}$ dan $\mathrm{H} 6, \Delta$ mean bernilai positif dan nilai signifikansi < 0,05. Positif menunjukan terjadi penurunan dan signifikansi $<0,05$ menunjukan penurunan terjadi secara sig- nifikan sehingga dapat disimpulkan Hipotesis $\mathrm{H}_{3}$ dan $\mathrm{H} 6$ diterima karena terjadi Penurunan secara signifikan pada Indikator Pengelolaan UP, dan Penyerapan Anggaran.

Dari sepuluh Indikator Kinerja Pelaksanaan Anggaran, hanya dua indikator yang menunjukan penurunan secara signifikan dan satu indikator yang menurun namun tidak signifikan. Hal ini menunjukan bahwa Kinerja Pelaksanaan Anggaran Satuan Kerja Lingkup Provinsi Kalimantan Barat secara umum tidak terpengaruh oleh Pandemi COVID-19 bahkan tetap dapat meningkat secara signifikan pada beberapa indikator kinerja.

\section{SIMPULAN DAN SARAN}

Indikator Kualitas Pelaksanaan Anggaran atau IKPA adalah indikator yang ditetapkan oleh Kementerian Keuangan selaku BUN untuk mengukur kualitas kinerja pelaksanaan anggaran belanja Kementerian Negara/Lembaga dari sisi kesesuaian terhadap perencanaan, efektivitas pelaksanaan anggaran, efisiensi pelaksanaan anggaran, dan kepatuhan terhadap regulasi. Adanya Pandemi COVID-19 pada tahun 2020 mengakibatkan satuan kerja (satker) sebagai ujung tombak dalam peningkatan kinerja pelaksanaan anggaran pada K/L menghadapi tantangan yang sangat berat. Berdasarkan hasil penelitian Dampak pandemi COVID-19 terhadap Kinerja Pelaksanaan Anggaran Satuan Kerja 
J1AD: Jurnal Ilmu Administrasi dan Pemerintahan Indonesia Volume 02 No 02 December 2021 Pages 12O-128

di Provinsi Kalimantan Barat, terdapat dua indikator yang menunjukan penurunan secara signifikan yaitu Indikator Pengelolaan UP, dan Indikator Penyerapan Anggaran serta satu indikator yang menurun namun tidak signifikan yaitu Indikator Penyelesaian Tagihan. Sedangkan tujuh indikator kinerja lainnya justru meningkat dengan rincian meningkat secara signifikan pada Indikator Pagu Minus, LPJ Bendahara, Dispensasi SPM, dan Kesalahan SPM dan meningkat namun tidak signifikan pada Data Kontrak, Retur SP2D, dan Renkas. Hal ini menunjukan bahwa Kinerja Pelaksanaan Anggaran Satuan Kerja Lingkup Provinsi Kalimantan Barat secara umum tidak terpengaruh Pandemi COVID-19 bahkan satuan kerja Lingkup Provinsi Kalimantan Barat tetap dapat meningkat kinerja pelaksanaan anggarannya secara signifikan pada beberapa indikator kinerja.

Meningkatnya kinerja pelaksanaan anggaran selama pandemi menunjukan kinerja satker telah baik dan pembinaan oleh KPPN selaku instansi pembina juga sudah tepat. Namun, Satker dan KPPN perlu memperhatikan dan memitigasi kembali dua indikator kinerja yang menurun yaitu Indikator Pengelolaan UP, dan Indikator Penyerapan Anggaran. Untuk meningkatkan nilai Pengelolaan UP dan TUP, Satuan kerja harus menggunakan UP dan TUP secara efektif dan mempercepat revolving UP dengan mengajukan SPM GUP minimal 1 (satu) kali dalam 30 hari. Satker juga dapat mengurangi jumlah UP pada periode selanjutnya apabila dirasa sulit untuk mempercepat revolving UP. Untuk indikator Penyerapan anggaran, Satker harus memastikan penyerapan anggaran triwulanan sudah sesuai target (15\%-40\%-60\%-90\%) dengan cara menyegerakan pencairan dan pelaksanaan kegiatan terutama belanja Modal yang memerlukan proses PBJ. Selain itu, perencanaan penarikan dana pada Halaman III DIPA juga perlu disesuaikan dengan target penyerapan agar kedua indikator tersebut dapat tercapai optimal secara bersamaan.

\section{DAFTAR PUSTAKa}

Cooper, D. R., \& Pamela, S. S. 2006. Metode Rise Bisnis. Jakarta: PT Media Global Edukasi.

Dinas Kesehatan Provinsi Kalimantan Barat. 2021. "Data COVID-19 Menurut Kabupaten/Kota Prov. Kalbar per 31 Desember 2020 pukul 21.00 wib" Diakses 21 November 2021 (http://data.kalbarprov.go.id/ dataset/data-covid-19-menurut-kabupatenkota-prov-kalbar-per-31-desember-2020-pukul-21-0o-wib).

Ghozali, Imam. 2006. Aplikasi Analisis Multivariate Dengan Program SPSS . Badan Penerbit Universitas Diponegoro. Semarang.

Given, L. M. (editor). 2008. The Sage Encyclopedia of Qualitative Research Methods. Thousand Oaks: Sage.

Gujarati, D. 2003. Ekonometri Dasar. (S. Zain, Ed.). Jakarta: Erlangga.

Indriantoro, N., dan Supomo, B. 2002. Metode Penelitian Bisnis untuk Akuntansi dan Manajemen. Yogyakarta: BPFE.

Kementerian Pendayagunaan Aparatur Negara dan Reformasi Birokrasi. 2009. "Reformasi Birokrasi" Diakses 21 November 2021 (https://www.menpan.go.id/ site/reformasi-birokrasi/makna-dan-tujuan).

Mardiasmo. 2009. Akuntabilitas Sektor Publik. Yogyakarta: Andi.

Pramana, Andi. 2012. Analisis Perbandingan Trading Volume Activity dan Abnormal Return Saham Sebelum dan Sesudah Pemecahan Saham (Studi Kasus Pada Perusahaan Yang Terdaftar di Bursa Efek Indonesia Periode 2007-2011). Semarang: Universitas Diponegoro.

Widiyanto. 2013. Statistika Terapan. Jakarta: PT Media Kompulindo.

WHO Indonesia. 2021. "Pertanyaan dan jawaban terkait Coronavirus" Diakses 20 November 2021 (https:// www.who.int/indonesia/news/novel-coronavirus/qa/qa-for-public).

Peraturan Menteri Keuangan nomor 195/PMK.05/2018 tentang Monitoring dan Evaluasi Pelaksanaan Anggaran Belanja Kementerian Negara/Lembaga menetapkan Indikator Kinerja Pelaksanaan Anggaran (IKPA).

Peraturan Menteri Keuangan Nomor PER-04/PB/2020 tentang Petunjuk Teknis Penilaian Indikator Kinerja Pelaksnaan Anggaran Belanja K/L.

Peraturan Pemerintah Nomor 21 Tahun 2020 tentang Pembatasan Sosial Berskala Besar (PSBB) dalam Rangka Percepatan Penanganan Corona Virus Disease 2019 (COVID-19).

Peraturan Menteri Keuangan Nomor 190/PMK.05/2012 tentang Tata Cara Pembayaran Dalam Rangka Pelaksanaan Anggaran Pendapatan Dan Belanja Negara

Peraturan Pemerintah Pengganti Undang-Undang Nomor 1 Tahun 2020 tentang Kebijakan Keuangan Negara dan Stabilitas Sistem Keuangan untuk Penanganan Pandemi Corona Virus Disease 2019 (COVID-19) dan/atau dalam Rangka Menghadapi Ancaman yang Membahayakan Perekonomian Nasional dan/ atau Stabilitas Sistem Keuangan.

Peraturan Presiden Nomor 54 Tahun 2020 tentang Perubahan Postur dan Rincian Anggaran Pendapatan dan Belanja Negara Tahun Anggaran 2020. 